\title{
Incidentally Detected Atrioventricular Septal Defect in an Adult
}

\author{
Risa Shimbori ${ }^{1}$, Jun Takaki², Yasuhito Hosoda², Ken Okamoto², Koji Fukae ${ }^{3}$, and \\ Toshihiro Fukui ${ }^{2}$ \\ ${ }^{1}$ Affiliation not available \\ ${ }^{2}$ Kumamoto University Hospital \\ ${ }^{3}$ Kumamoto City Hospital
}

May 5, 2020

\begin{abstract}
A 34-year-old woman was referred to our hospital for inspection before operation for liver transplantation as a donor for her son. She had no symptoms and remarkable medical history. Echocardiography showed a defect in lower part of the atrial septum with a cleft of left atrioventricular valve and right atrioventricular valve regurgitation. She was diagnosed as incomplete atrioventricular septal defect for the first time. She underwent double valve repair and patch closure of the atrioventricular septal defect. It is a rare case for atrioventricular septal defect in adulthood incidentally detected without symptoms.
\end{abstract}

\section{Introduction}

Atrioventricular septal defect is a group of diverse malformations unified by having the same characteristic morphology at their atrioventricular septal junction. It account for about 7-17\% of congenital heart disease [1]. Most patients undergo operation in childhood and the long-term survival after operation is favorable. However, a few patients with incomplete atrioventricular septal defect are diagnosed in adulthood. It is suggested that the delayed operations rise ratio to additional preoperative complications and influences cardiac function [2]. Here, we report a rare case of adult patient with incomplete atrioventricular septal defect that were incidentally detected without symptom.

Case Report

A 34-year-old woman was referred to our hospital for inspection before operation for liver transplantation as a donor for her son. She had no symptom and no remarkable medical history. She had a history of successful vaginal delivery. When she was admitted to our hospital, Cardiac auscultation showed a grade $3 / 6$ ejection systolic murmur at the second left sternal border, and the second heart sounds were fixed splitting. Twelvelead electrocardiography showed sinus rhythm, left axis deviation, incomplete right bundle blanch block pattern (Figure 1A). Two-dimensional echocardiography revealed preserved left ventricular contractility; however, the atrium and right ventricle were dilated. Moreover, there was a defect in the lower part of the atrial septum and ventricular septal defect (VSD) closed with fibrous tissue. Color Doppler echocardiography showed left atrial to right atrial shunt, mild-moderate left atrioventricular valve (LAVV) regurgitation and moderate right atrioventricular valve(RAVV) regurgitation (Figure 1B). The cardiac catheterization showed gooseneck deformity (Figure 1C). Right heart catheterization demonstrated the mean pulmonary artery pressure was $16 \mathrm{mmHg}$, and mean pulmonary capillary wedge pressure was $10 \mathrm{mmHg}$. A pulmonary to systemic flow ratio was 2.08 .

She was diagnosed as an incomplete atrioventricular septal defect (AVSD). Even though she had no symptoms, we decided her not to be a donor of liver transplantation, and to be undergone a repair of AVSD. After median sternotomy, cardiopulmonary bypass and aortic cross clamping were performed as usual. We 
observed a defect in the lower part of the atrial septum and a very small VSD surrounded by fibrous tissue and a cleft of LAVV (Figure 2A). It was intermediate type AVSD. At first, the pericardium was sutured to the junction of the RAVV and LAVV annulus and the small VSD was closed by direct suture (Figure 2B). Suturing in the area of the atrioventricular node and coronary sinus was performed very close to the LAVV. Next, the cleft of LAVV was closed with interrupted sutures and edge-to-edge repair for RAVV regurgitation.

Postoperatively, two-dimensional echocardiography demonstrated no leak around pericardial patch. Both RAVV and LAVV regurgitations were trivial (Figure 3). Her postoperative course was uneventful.

\section{Comment}

is classified into four groups: complete, partial with an isolated primum ASD, partial with an isolated inlet VSD and intermediate type. Intermediate AVSD is anatomically characterized by the presence of an ostium primum atrial septal defect occupying the portion of the atrial septum just superior to the separately formed RAVV and LAVV, and varying degrees of clefting of the anterior leaflet of the LAVV $[1,3]$. Intermediate type AVSD is less frequent than complete or partial AVSD, and is tartly encountered in the adulthood [4].

Complete AVSD presents early in life, and unless treated expediently develop into irreversible pulmonary vascular disease. Presentation of incomplete or intermediate AVSD is more variable. The optimum age for repair of incomplete AVSD is 3 to 5 years, but some patients diagnosed by presenting congestive heart failure symptoms in adult [5]. The outcome is excellent after the repair of incomplete AVSD in childhood.

Michael et al. reported the long-term survival after repair of incomplete AVSD in adult [2]. Pulmonary arterial hypertension, complete AV block and atrial arrhythmias were the risk factors of mortality and morbidity. They recommended the early surgery for AVSD to reduce the risk because older patients are more likely to present with atrial arrhythmia and moderate or severe RAVV regurgitation.

Our patient was fortunately detected incidentally before having bad preoperative condition. Moreover, her cardiac function was preserved without any arrhythmia. We believe that it is important for cardiologist to know there is a chance to see patient with AVSD without symptoms incidentally in adulthood.

Conflict of Interest:

None declared.

\section{Author Contributions:}

Drafting article: Risa Shimbori, Jun Takaki, Hosoda Yasuhito, Ken Okamoto, Koji Fukae

Critical revision: Toshihiro Fukui

\section{References}

1. Song L, Ling Y, An Q. Repair of partial atrioventricular canal defect in adult patients: two-year follow-up outcomes of a retrospective study. J Cardiothorac Surg 2019;14:106

2. Gatzoulis MA, Hechter S, Webb GD, Williams WG. Surgery for partial atrioventricular septal defect in the adult. Ann Thorac Surg 1999;67:504-510

3. Murashita T, Kubota T, Oba J, Aoki T, Matano J, Yasuda K. Left atrioventricular valve regurgitation after repair of incomplete atrioventricular septal defect. Ann Thorac Surg 2004;77:2157-2162.

4. Shoh Tateve, MD, PhD, Yoshiaki Saji, MD, PhD, Kenji Aoki, MD, Setsui Kuraoka, MD, PhD: Intermediate Type Atrioventricular Septal Defect in the Elderly. Ann Thorac Surg 2006;81:1888-1890. 
5. De Angelis F, Savino K, Colombo A, Sardone M, Ambrosio G. Never too grown-up for a congenital heart disease: Diagnosis of transitional atrioventricular canal in a 50-year-old male. J Cardiovasc Echogr 2019;29:35-38.

\section{Figure Legends}

Figure 1: (A)Twelve-lead electrocardiography showed sinus rhythm, left axis deviation, incomplete right bundle blanch block pattern. (B) Four chamber view of transthoracic echocardiogram shows a left atrial to right atrial shunt. (C) Cardiac catheterization shows gooseneck deformity. (LV =left ventricle, LA =left atrium, $\mathrm{RV}=$ right ventricle, $\mathrm{RA}=$ right atrium)

Figure 2: Operation. (A) The cleft of mitral valve. (B) Pericardial patch is sutured in place to close atrial component of defect. Coronary sinus remains draining to right atrium. ( $\mathrm{CS}=$ coronary sinus, $\mathrm{MV}=$ mitral valve, $\mathrm{RA}=$ right atrium)

Figure 3: Post-operative transthoracic echocardiogram, there was no leak around pericardial patch. (LV $=$ left ventricle, $\mathrm{LA}=$ left atrium, $\mathrm{RV}=$ right ventricle, $\mathrm{RA}=$ right atrium)

\section{Hosted file}

Figure1A.pptx available at https://authorea.com/users/316881/articles/446989-incidentallydetected-atrioventricular-septal-defect-in-an-adult

\section{Hosted file}

Figure1B.pptx available at https://authorea.com/users/316881/articles/446989-incidentallydetected-atrioventricular-septal-defect-in-an-adult

\section{Hosted file}

Figure1C.pptx available at https://authorea.com/users/316881/articles/446989-incidentallydetected-atrioventricular-septal-defect-in-an-adult

\section{Hosted file}

Figure2A.pptx available at https://authorea.com/users/316881/articles/446989-incidentallydetected-atrioventricular-septal-defect-in-an-adult

\section{Hosted file}

Figure2B.pptx available at https://authorea.com/users/316881/articles/446989-incidentallydetected-atrioventricular-septal-defect-in-an-adult

\section{Hosted file}

Figure3.pptx available at https://authorea.com/users/316881/articles/446989-incidentallydetected-atrioventricular-septal-defect-in-an-adult 